\title{
Influence of Locally Sourced Additives on Neem Plant Organic Fertilizer Quality in Samaru, Zaria, Kaduna State, Nigeria
}

\author{
*11 IBRAHIM, D; ${ }^{1}$ DANMALAM, AA ; ${ }^{1}$ SALIHU, AI; ${ }^{2}$ JAJERE, UM
}

\author{
${ }^{I * N a t i o n a l ~ r e s e a r c h ~ i n s t i t u t e ~ f o r ~ C h e m i c a l ~ T e c h n o l o g y, ~ B a s a w a-Z a r i a, ~ K a d u n a ~ S t a t e, ~ N i g e r i a ~}$ \\ ${ }^{2}$ Department of Pharmacognosy and Drug Development, Faculty of Pharmaceutical sciences, Gombe State University. Gombe, Nigeria \\ *Corresponding Author Email: thrbrhm@gmail.com
}

\begin{abstract}
Neem samples (Neem fruit, Neem Cake and oil) were prepared using locally sourced materials, the Neem oil was obtained during the caking, while the Neem fruit was simply air-dried. The results showed that all the Neem samples contained: Nitrogen, Phosphorous and Potassium considerable for fertilizer production but Neem fruit has the highest percentage of Nitrogen 3.3\%, Phosphorous $4.1 \%$ and potassium $3.8 \%$ while the oil has the least content of $1.1 \%$ Nitrogen, $2.0 \%$ Phosphorous and $1.1 \%$ potassium. Additives were introduced in the production to enhance the quality of the fertilizer such as limestone to neutralize the soil, poultry liter as supplement of the nitrogen, phosphorous and potassium content of the fertilizer, Rock phosphate to standardize the phosphorous content of the soil and to retain the soil texture and composition.
\end{abstract}

\section{DOI: https://dx.doi.org/10.4314/jasem.v22i8.4}

Copyright: Copyright $(92018$ Ibrahim et al. This is an open access article distributed under the Creative Commons Attribution License (CCL), which permits unrestricted use, distribution, and reproduction in any medium, provided the original work is properly cited.

Dates: Received: 12 May 2018; Revised: 26 June: 2018; Accepted: 30 July 2018

Keywords: Neem fruit, Neem cake, Neem seed, Rock phosphate, Organic fertilizer

Fertilizer (fertilizer in British English) is any material of natural or synthetic origin (other than liming materials) that is applied to soils or to plants tissues (usually leaves) to supply one or more plants nutrients essential to the growth of plants. Conservative estimates report 30 to $50 \%$ of crop yields are attributed to natural or synthetic commercial fertilizer, (Mill, 1996). Neem tree, Azadiracta indica is a tree belonging to the member of Mahogany family meliaceae. Neem tree is attractive, broad-leaved ever green that can grow up to $30 \mathrm{~m}$ height and 2.5 in girth. The roots penetrate the soil deeply and if injured they produce suckers. The suckering tends to be especially prolific in dry localities. Its flowers are small, white and borne in auxiliary clusters. Neem honey is alsopopular and reportedly contains no trace of Azadiractin (main chemical identified for insecticide properties). Its fruit is ellipsoidal, smooth, yellow or greenish yellow in color comprising of sweet pulp enclosing a seed. The seed is composed of a shell and kernel (sometimes 2 or 3 kernels) each about half the seed weight. On average neem kernel contain 2 and $4 \mathrm{mg}$ of Azadiracta per gramm of kernel. Neem tree normally bear fruit after 3-5 years. It may live for more than two centuries. Nitrogen, phosphorous and potassium are the three macro nutrient in common fertilizers (Jerrell, 1981). Fertilizer is mostly classified in to: organic fertilizer which is derived from living organisms, plant or animals like man waste or crop etc. and inorganic fertilizer which is derived from nonliving source like man-made activities (Benton, 2012). Neem cake has an adequate quantity of NPK in organic form for plant growth. Being a totally botanical product it contains $100 \%$ natural NPK content and other essential micro nutrients as $\mathrm{N}$ (Nitrogen $2.0 \%$ to $5.0 \%$ ), $\mathrm{P}$ (Phosphorus $0.5 \%$ to $1.0 \%$ ), K (Potassium $1.0 \%$ to $2.0 \%$ ), Ca (Calcium $0.5 \%$ to $3.0 \%$ ), $\mathrm{Mg}$ (Magnesium $0.3 \%$ to $1.0 \%$ ), $\mathrm{S}$ (Sulphur $0.2 \%$ to $3.0 \%$ ), Zn (Zinc $15 \mathrm{ppm}$ to $60 \mathrm{ppm}$ ), $\mathrm{Cu}$ (Copper $4 \mathrm{ppm}$ to $20 \mathrm{ppm}$ ), Fe (Iron $500 \mathrm{ppm}$ to $1200 \mathrm{ppm}$ ), Mn (Manganese $20 \mathrm{ppm}$ to $60 \mathrm{ppm}$ ). It is rich in both sulphur compounds and bitter limonoids (Schmutterer, 2002). According to research calculations, neem cake seems to make soil more fertile due to an ingredient that blocks soil bacteria from converting nitrogenous compounds into nitrogen gas. It is a nitrification inhibitor and prolongs the availability of nitrogen to both short duration and long duration crops (Tewari, 1992). Neem cake organic manure protects plant roots from nematodes, soil grubs and white ants probably due to its residual limonoid content. It also acts as a natural fertilizer with pesticidal properties. Neem cake is widely used in India to fertilize paddy, cotton and sugarcane. Usages 
of neem cake have shown an increase in the dry matter in Tectona grandis (Teak), Acacia nilotica (Gum Arabic), and other forest trees (Tewari, 1992). Neem seed cake also reduces alkalinity in soil, as it produces organic acids on decomposition. Being totally natural, it is compatible with soil microbes and rhizosphere microflora and hence ensures fertility of the soil (Puri, 1999). Neem cake improves the organic matter content of the soil, helping improve soil texture, water holding capacity, and soil aeration for better root development (Vietmeyer, 1992). Neem cake is effective in the management of insects and pests. The bitter principles of the soil and cake have been reported to have seven types of activities (a) antifeedant (b) attractant (c) repellent (d) insecticide (e) nematicide (f) growth disruptor and (g) antimicrobial ( Puri, 1999). The cake contains salannin, nimbin, azadirachtin and azadiradione as the major components. Of these, azadirachtin and meliantriol are used as locust antifeedants while salannin is used as an antifeedant for the housefly (Puri, 1999). In this research work neem samples: neem cake, oil, and fruit was analyzed to determine the percentages of nitrogen, phosphorous and potassium contents, then additives such as poultry liter, rock phosphate and limestone to influence the percentages of the elements in the samples

\section{MATERIALS AND METHODS}

Neem fruit obtained from Samaru, Hayin Dogo, Zaria, Kaduna state Nigeria.

Distilled water, $50 \% \mathrm{~W} / \mathrm{W}$ sulphuric acid, $50 \% \mathrm{~W} / \mathrm{W}$ hydrochloric acid, mixed catalysts copper sulphate and potassium sulphate

Table 1: Analysis of the following samples for fertilizer production

\begin{tabular}{|c|c|c|}
\hline $\mathrm{S} / \mathrm{N}$ & Symbol & Name \\
\hline & & Neem cake \\
\hline & & Neem fruit \\
\hline & & Neem oil \\
\hline
\end{tabular}

Methodology: The following figure (1) and described selected processing steps, using Thai Neem Product Company limited

Neem caking: The neem caking was determined following the method of Julius, (1910). 50grams of the Neem fruit was air dried for 10 days, it is essential to dry the fruits so that their moisture content is lower than $10 \%$ and softly grinded to remove the shell (outer layer) in order to obtain the seed. The seed was airdried for 2 days, crushed using mortar and pestle, then was spread on tray and sprinkled with little amount of water which was placed in an oven for one hour at $45^{\circ} \mathrm{C}$, pressed using mechanical presser
Digestion of sample: The sample digestion was determined following the method of Kjeldahhl, (1983) $1.5 \mathrm{~g}$ of the sample was put in to $300 \mathrm{ml} \mathrm{Kjeldahl} \mathrm{flasks}$ A, B and C. $25 \mathrm{ml}$ of sulphuric acid $\left(\mathrm{H}_{2} \mathrm{SO}_{4}\right)$ and $3 \mathrm{~g}$ of mixed catalysts copper sulphate and potassium sulphate $\left(\mathrm{CUSO}_{4}\right.$ and $\left.\mathrm{K}_{2} \mathrm{SO}_{4}\right)$ were placed in these kjeldahl flasks respectively. The Neem cake was digested for 24 hours until a clear green color was obtained. The digested solution was cooled and diluted to $100 \mathrm{ml}$ with distilled water

Distillation and Titration: The titrations of the sample were determined by following the procedure described by Standard method for the examination of water and wastewater, (1992): $20 \mathrm{ml}$ of diluted digest was measured in to $500 \mathrm{ml}$ kjeldahl flask containing antibumping chips and $40 \mathrm{ml}$ of $40 \% \mathrm{NaOH}$ was slowly added to the flask. $50 \mathrm{ml}$ of $2 \%$ of boric acid and 4 drop of mixed indicator were dropped in to 25 $\mathrm{ml}$ conical flask. The conical flask and the Kjeldahl flask were then placed on Kjeldahl distilation apparatus with the tube inserted in to the conical flask and the Kjeldahl flask. The Kjeldahl falsk was heated and the distillate was collected in to the boric acid solution. From the point when the boric acid turns green, it allowed for 10minutes for complete distillation of the ammonia present in the digest. The distillate was then titrated with 1.0MM HCL

Analysis of phosphorous and potassium: The analysis of phosphorous and potassium was determined following the method of Bjerrum, (1958); Kolthoff et al., (1941): 1 gram of the sample was measured and introduced in to beaker; $5 \mathrm{ml}$ of concentrated nitric acid and $15 \mathrm{ml}$ of Hydrochloric acid was added and heated for 45 minute on hot plate. $10 \mathrm{ml}$ of distilled water was added and was allowed to cool for 45 minutes, after cooling the solution was put in to white bottle through filter paper which was diluted again with distilled water to top it to $100 \mathrm{ml}$. spectrophotometer was used to analyzed phosphorous while potassium was analyzed using flame photometer.

Analysis of the fertilizer produced from the samples plus additives: The analysis of phosphorous and potassium was determined following the method of Bjerrum, (1958); KKolthoff et al., (1941): 1 gram of the fertilizer produced was introduced in to a beaker and $15 \mathrm{ml}$ concentrated sulphuric acid $\left(\mathrm{H}_{2} \mathrm{SO}_{4}\right)$ and concentrated nitric acid $\left(\mathrm{HNO}_{3}\right)$ were added respectively which was placed on hot plate for 
45 minutes for digestion. $10 \mathrm{ml}$ of distilled water was added and allow to cool, after cooling, the solution was filtered with filter paper and tapped with distil to 100 $\mathrm{ml}$ in white sample bottle. Spectrophotometer was used to analyzed phosphorous while potassium was analyzed using flame photometer

\section{RESULTS AND DISCUSSION}

The Kjeldahl apparatus consist of three flasks in which the percentages of the nitrogen present in the sample is calculated. Table 2 showed the percentages of nitrogen in sample by which average percentage value was taken. Sample is the Neem fruit, Neem cake and the Neem oil. Kjeldahl apparatus is used to analyze nitrogen content on a given sample (material). (Onyeika, 2003). From Table 3, the Neem fruit has $3.3 \%$ Nitrogen, $4.1 \%$ Phosphorous and 3.8\% Potassium, making it more suitable for fertilizer production compared to Neem cake and Neem oil which has lower percentage of Nitrogen, Phosphorous and Potassium. Therefore, due to the highest percentages of the elements in the fruits it was then used in the production of the fertilizer by adding some local additives. Micronutrients are consumed in smaller quantities and are present in plant tissues on the order of part-per-million (PPM), ranging from 0.15 to $400 \mathrm{ppm}$ DM, or less than $0.04 \%$ DM. Mills and Jones (1996).

Table 2: Titer value of nitrogen analysis using Kjeldahl appartus

\begin{tabular}{llllll}
\hline No & Kjeldahl flask & $\begin{array}{l}\text { Titer } \\
(\mathrm{ml})\end{array}$ & value & $\begin{array}{l}\text { Percentage } \\
\text { nitrogen }\end{array}$ & of \\
\hline & A' & 0.6 & 2.1 & \\
& B' & 0.5 & 2.0 & \\
C' & 0.4 & 2.5 & \\
\hline
\end{tabular}

Table 3: Analysis of NPK in Neem fruit, Neem cake and Neem oil

\begin{tabular}{llll}
\hline Samples & Nitrogen $(\mathrm{N})$ & Phosphorus $(\mathrm{P})$ & Potassium $(\mathrm{K})$ \\
\hline Neem cake & $2.2 \%$ & $2.1 \%$ & $2.7 \%$ \\
Neem fruit & $3.3 \%$ & $4.1 \%$ & $3.8 \%$ \\
Neem oil & $1.1 \%$ & $2.0 \%$ & $1.1 \%$ \\
\hline
\end{tabular}

Water Absorption Properties of The Additives: Fig 1 shows that $25 \%$ additive has better water absorption properties at $11 \%$ than other percentage. At $30 \%$ additive the water absorption properties decrease to $2 \%$ due to continue agglomeration of the additives on the Neem sample, therefore $25 \%$ additive has been chosen for the production of the organic Fertilizer. Table 5 showed that the produced (Neem fruits plus the local additives) contained Nitrogen (N) 6\%, Phosphorous (P) 7.0\% and Potassium (K) 6.9\%. NPK fertilizers are three- component fertilizers providing nitrogen, phosphorus and potassium. NPK rating is a rating system describing the amount of nitrogen, phosphorous, and potassium in a fertilizer. NPK ratings consist of three numbers separated by dashes (e.g 10-10-10 or 16-4-8). Label requirements $s$ of specialty and other bagged fertilizers, (2013).

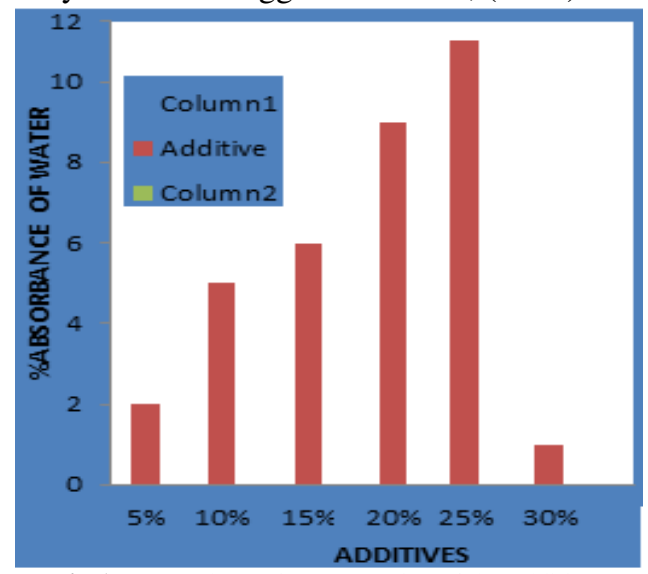

Fig 1: water absorption properties of the additives

Table 4: proportion of additives used in the fertilizer production

\begin{tabular}{ll} 
Additives & Percentages $(\%)$ \\
Limestone & 25 \\
\hline Rock phosphate & 25 \\
Poultry liter & 25 \\
\hline
\end{tabular}

Table 5: Analysis of NPK in the product after introducing the additives (Limestone, Poultry liters and Rock phosphate)

\begin{tabular}{ll}
\hline Content & Percentage $(\%)$ \\
\hline Nitrogen (N) & 6.0 \\
Phosphorous (P) & 7.0 \\
Potassium (K) & 6.9 \\
\hline
\end{tabular}

Conclusion: Neem fruit was found to contain high percentage of nitrogen, phosphorus and potassium which was blended with additive (poultry liter, limestone and rock phosphate) resulted in to nitrogen of $6.0 \%$, phosphorous $7.0 \%$ and potassium $6.9 \%$ organic fertilizer.

\section{REFERENCES}

Bjerrum, J., "stability consistence, Part II: Inorganic Ligands", P. 61, The Chemical Society, London, $1958 \mathrm{~S}$

Jarrel, M. (1981). 'The dilution effect in plant nutrition studies’ Adv. Agro. India. 3: 97-224

Julius B. Cohen practical Organic Chemistry the 6th Edition. pp. 61. 1990

Kjeldahl, J. (1983) "Neue methole zur bestimimung des stickstoffs in organischen korpem" (New methods for the determination of nitrogen in 
organic substances) Zeitschrift fur analytische chemie, 22(1): 366 - 383

Kolthoff, I. M., and Lingane, J. J., “polagraphy”, New York, intersecince publishers, 1941

Label requirements of specialty and other bagged fertilizers. Michigan Department of Agriculture and Rural Development. Retrieved 14 March 2013

Mill, J.B. Jones, Jr. (1996). Plant Handbook II: A practical sampling, preparation, analysis and interpretation guide: ISBN 1-978148-05-2

Onyeika EN, Osuji JO 2003: Research Techniques in Biological and Chemical Science Springfield publisher Ltd. Owerri.

Puri, H.S. (1999) Neem: The Divine Tree. Azadirachta indica. Harwood Academic Publishers, Amsterdam. ISBN 90-5702-348-2
Schmutterer, H. (Editor) (2002). The Neem Tree: Source of Unique Natural Products for Integrated Pest Management, Medicine, Industry And Other Purposes (Hardcover), 2nd Edition, Weinheim, Germany: VCH Verlagsgesellschaft. ISBN 3527-30054-6

Standard methods for the examination of water and wastewater $15^{\text {th }}$ edition 1992 page $4-40$,

Tewari, D. N. (1992), Monograph on neem (Azadirachta indica A. Juss.). Dehra Dun, India: International Book Distributors. pp. 123-128 ISBN 81-7089-175-2

Vietmeyer, N. D. (Director) (1992). Neem: A Tree for Solving Global Problems. Report of an ad hoc panel of the Board on Science and Technology for International Development, National Research Council, Washington, DC, USA: National Academy Press. Pp.74-75. ISBN 0-309-04686-6

Yash-Roy R.C. and Gupta P.K (2000). Neem-seed oil inhibits growth of termites' surface- tunnels. India J. Toxic. 7(1), pp. 49-50 